\title{
GREEN FUTURE
}

\author{
But is it art?
}

\section{BY DEBORAH WALKER}

" $\mathrm{H}$ ey, Mrs M."

Miriam ignores the boy. She pushes her way through the tangled undergrowth of Trafalgar Square, past the stone lions with their impassive eyes virtually obscured by their liana manes. She must remember to bring a pair of shears tomorrow.

"Hold on. Hold on." The boy skips through the waist-high vegetation. He'll catch her soon enough. He's a kid from the Bloomsbury favela, born and bred to London's jungle. His name is Crich, and he's been bothering Miriam for a couple of months. Rather than let him overtake her, Miriam waits for him. Crich runs up. His smile gleams in his greenflecked face. Miriam's face is clean; she washes herself properly, every morning.

"Hey, Mrs M. What are you doing? You cleaning, again?"

"Yes, Crich. I'm cleaning, again. Somebody's got to do it."

Miriam has always been a cleaner. A long time ago, she'd worked in an office. Now, she has a more important cleaning job.

"You sure like cleaning."

"I do."

"Mama says that you should come home and live with us."

"Does she, indeed?"

Mama isn't his real mother. The favelas have developed their own customs. Mama is the head of Crich's tribe.

"Can I come with you, Mrs M?"

"Can I stop you?"

He grins. They cross the square and climb the steps of the National Gallery. Crich chats about the comings and goings of his tribe: a girl he likes; a cache of food tins the scouts had found squirrelled in a forgotten basement; a trade agreement with the Islington favela. Miriam thinks about which picture she should restore. She flicks through the catalogue of her mind and decides upon the Venus. When they reach the top of the stairs, Miriam pauses, to catch her breath.

"You alright, Mrs M?" asks Crich.

"I'm not as young as I used to be," says Miriam with a wry smile. She sighs and rubs her hip. "No rest for the wicked," she mutters. "Come on, young man, let's get going." She collects her cleaning equipment, which she keeps hidden behind the customer information desk.

"Which picture, today?" asks Crich.

"Velázquez's Venus, it's on the ground floor."

"I know the way," says Crich. He steps quickly though the gallery. Miriam follows him. She walks carefully, trying to minimize the pain in her hip. Miriam sighs when sees the corner of the room. "Go on. Clear out of here." She snaps a tea-towel at the nest, and the rats scurry out of the gallery.

"There's good eating on those things," remarks Crich. Miriam ignores him. She places the folding table close to the Venus, and sets out the tray. She pours a quantity the family of green-black rats, chattering in

smudge of red-bloom for a mouth, weaving tendrils for the hair.

"It's a picture of Mama," explains Crich.

"Did you make this, Crich?"

"Sure did. Everyone's making them. Mine's not so good, really. You should see some of the others." Miriam stares at the picture. Art out of algae.

"Mama doesn't like you out here, living by yourself," says Crich. "She says you should be with your family."

"I need to be close to the gallery."

"The thing about my picture, Mrs M, is that it grows. It changes. New colonies of air-borne algae adhere to the surface. That golden web of tendrils across her cheek wasn't there yesterday."

Miriam hands the picture back to Crich. "I'm sure it's very nice, but I've never really cared for modern art." Miriam packs up her cleaning tools.

"You'll come home with me today," says Crich. It's a statement, not a question.

"But I've got to clean the paintings. Somebody's got to do it."

“No, Mrs M. We've got our own art, now. You'll come home with us." He looks at her and grins. "And we sure could do with someone who likes to clean up."

"Somebody's got to clean the pictures." of bleach solution into the tray and wets her cotton rag. Slowly, she applies the weakwater bleach to the old master and wipes away the film of algae. Slowly, the pink flesh of the reclining Venus is revealed.

"She sure is fat," says Crich.

"She is."

"But she's pretty."

"She's clean now." Miriam steps back to admire her work.

"Clean, but not for long," says Crich.

Miriam's work is done for the day. She will return home, and think about things. Think about things past.

"I want to show you something," says Crich. He takes a sheet of paper from his bag and hands it to Miriam.

Miriam stares at the green-brown image, an oval-shape of algae colonies, clustered onto the paper. It was a face, a

\section{DNATURE.COM}

Follow Futures on Facebook at:

go.nature.com/mtoodm
"No more old pictures," says Crich. There's insistence in his voice. Miriam realizes that Crich is older than she thought. When did he get so old? And when did she get so old?

"Let me have another look at that picture of yours." Crich passes her the portrait.

"Will you come home with me? Please, Mrs M."

"Maybe I will come - just for a short visit," she says. Miriam looks at the reclining Venus. She was so beautiful, but was it time to leave her behind? Perhaps there were other things to see in this hot, green world.

"Let's go home, Mrs M." Crich picks up Miriam's cleaning equipment. He gently takes her arm, and he leads her, slowly, out of the National Gallery.

Deborah Walker lives in London. Find her in the British Museum, nicking ideas from ancient cultures. 